\title{
Observations on the reproductive biology of three catsharks (Carcharhiniformes: Scyliorhinidae: Asymbolus and Figaro) from the continental shelf of southern Queensland, Australia
}

\author{
PETER M. KYNE ${ }^{1,2}$, ANTHONY J. COURTNEY ${ }^{3}$ AND MICHAEL B. BENNETT 4 \\ ${ }^{1}$ School of Biomedical Sciences, University of Queensland, St Lucia, Queensland, 4072, Australia, ${ }^{2}$ Present address: Tropical Rivers \\ and Coastal Knowledge, Charles Darwin University, Darwin, Northern Territory, 0909, Australia, ${ }^{3}$ Southern Fisheries Centre, \\ Department of Employment, Economic Development and Innovation, Deception Bay, Queensland, 4508, Australia, ${ }^{4}$ School of \\ Biomedical Sciences, University of Queensland, St Lucia, Queensland, 4072, Australia
}

\begin{abstract}
Three species of Australian endemic catsharks (grey spotted catshark Asymbolus analis, orange spotted catshark A. rubiginosus and Australian sawtail shark Figaro boardmani) were collected from the trawl grounds of a highly seasonal commercial fishery off southern Queensland, Australia. Specimens were collected on the mid to outer continental shelf at depths between 78 and $168 \mathrm{~m}$. This study provides the first information on the reproductive biology of these three poorly-known species. Mature female and male A. analis were observed from $455 \mathrm{~mm}$ total length (TL), mature female A. rubiginosus from $410 \mathrm{~mm}$ TL, mature male A. rubiginosus from $405 \mathrm{~mm}$ TL, mature female F. boardmani from $402 \mathrm{~mm}$ TL and mature male F. boardmani from $398 \mathrm{~mm}$ TL (although a lack of immature specimens precluded more accurate assessments of size at maturity). The reproductive mode of all species was confirmed as single oviparous (carrying only one egg case in each uterus at a time). Ovarian fecundity (the number of vitellogenic follicles) ranged from 7-20 in A. analis, 5-23 in A. rubiginosus and 9-13 in F. boardmani. Several indicators suggest that Asymbolus catsharks off southern Queensland are reproductively active year-round. The proportion of female A. rubiginosus carrying egg cases was highest in spring (60\%), intermediate in autumn (50\%) and lowest in winter (44\%).
\end{abstract}

Keywords: Scyliorhinidae, Asymbolus analis, Asymbolus rubiginosus, Figaro boardmani, Queensland, East Coast Trawl Fishery, size at maturity, reproductive seasonality

Submitted 13 April 2010; accepted 20 August 2010; first published online 18 October 2010

\section{INTRロDUCTION}

The catsharks (Elasmobranchii: Carcharhiniformes: Scyliorhinidae) represent the most speciose shark family with $120+$ valid species recognized globally (updated from Compagno, 2005). While the family is global in occurrence, many species have limited distributions. The Australasian region has a high degree of endemism, with 34 scyliorhinid species recorded from Australian waters (Compagno et al., 2005; Last \& Stevens, 2009). Despite their diversity, the family remains poorly-known, with limited to no biological or ecological information available for the vast majority of species. Apart from published studies on the common inshore draughtboard shark Cephaloscyllium laticeps (Duméril, 1853) of southern Australia (Awruch et al., 2008, 2009), and some limited reports on sizes at sexual maturity (Last \& Stevens, 2009), information on the reproductive biology of Australian scyliorhinid sharks is lacking.

Corresponding author:

P.M. Kyne

Email: peter.kyne@cdu.edu.au
The demersal elasmobranch fauna of the outer continental shelf and upper slope off southern Queensland (eastern Australia) includes three poorly-known Australian endemic catsharks: grey spotted catshark Asymbolus analis (Ogilby, 1885) (eastern Australia from southern Queensland to Victoria; 25$200 \mathrm{~m}$ depth); orange spotted catshark Asymbolus rubiginosus Last, Gomon \& Gledhill, in Last, 1999 (eastern Australia from southern Queensland to Tasmania; 25-540 m depth); and Australian sawtail shark Figaro boardmani (Whitley, 1928) (eastern, southern and western Australia from southern Queensland to Western Australia including Tasmania; 130$640 \mathrm{~m}$ depth) (Last et al., 1999; Kyne et al., 2005; Last \& Stevens, 2009; present study). Kyne et al. (2005) provided some basic information on reproduction in A. analis, but this was based on only five dissected mature females.

These three catshark species are discarded bycatch of the Queensland East Coast Trawl Fishery (QECTF), a multi-species benthic commercial fishery targeting prawns (Penaeidae) and scallops (Pectinidae). Off southern Queensland, the large eastern king prawn Penaeus plebejus is fished on the outer continental shelf in a seasonal (generally between May and August) 'deepwater' fishery in depths of 90-300 m. Catshark specimens 
were primarily collected from the trawl grounds of this deepwater sector of the QECTF (though some specimens were collected from a shallower water sector of the QECTF, where catshark bycatch is irregular) in order to address knowledge gaps in their basic biology. This paper presents preliminary information on the reproductive biology (sex-ratios, size at maturity, reproductive mode, reproductive seasonality and ovarian fecundity) of A. analis, A. rubiginosus and F. boardmani from southern Queensland.

\section{MATERIALS AND METHDDS}

Specimens were collected between March 2001 and February 2004 from the mid to outer continental shelf (depths of $78-$ $168 \mathrm{~m})$ off southern Queensland, Australia $\left(26^{\circ} 31^{\prime}-27^{\circ} 49^{\prime} \mathrm{S}\right.$ $\left.153^{\circ} 31^{\prime}-153^{\circ} 50^{\prime} \mathrm{E}\right)$ (Table 1 ). The vast majority of specimens were collected from a highly seasonal sector of the Queensland trawl fishery; the fishery generally operates between May and August. Outside of these months, vessels fish waters shallower than about $90 \mathrm{~m}$ depth and catshark by catch is minimal. This limited both the number of specimens available for examination and the months/seasons in which specimens were collected. Therefore, the vast majority of specimens were collected from only a few months, mostly in winter, with almost no sampling conducted in summer (with only one specimen collected in summer from the shallow water sector of the fishery) (Table 1). Data from specimens of $A$. analis ( $\mathrm{N}=5$ females) examined by Kyne et al. (2005) were incorporated into the full dataset for that species presented here. Collection was by commercial otter-board trawlers fitted with three 2-seam Florida Flyer nets (net body mesh size $50.8 \mathrm{~mm}$, codend mesh size 44.5 or $47.6 \mathrm{~mm}$ ) with headrope lengths of 12.8 or $22.0 \mathrm{~m}$. Catsharks were snap-frozen at sea.

Total length (TL), the distance from the tip of the snout to the distant margin of the caudal fin was measured on the ventral surface to the nearest millimetre. Mass was measured to the nearest gram. Maturity stages were assessed for males and females (Ellis \& Shackley, 1997; Ebert et al., 2006). Males were classed as immature (if they possessed short, uncalcified claspers, undeveloped testes), adolescent (claspers extended but uncalcified, developing testes) or mature (calcified and elongated claspers, testes developed and lobular, epididymides highly coiled). Females were classed as immature (undeveloped ovaries, undifferentiated oviducal glands, thin uteri), adolescent (incompletely developed ovaries with only small white follicles $\leq 4 \mathrm{~mm}$ diameter, incompletely developed oviducal glands, slightly expanded uteri) or mature (developed ovaries with yellow vitellogenic follicles $\geq 5 \mathrm{~mm}$ diameter, fully developed oviducal glands, uteri and egg cases may be present).

Reproductive systems were removed and testes and ovaries (both with attached epigonal tissues) were weighed to the nearest decigram. Inner clasper length $(\mathrm{CL})$ was measured in males to the nearest millimetre, from the point of insertion of the pelvic fin to the posterior tip of the longest clasper. To examine the onset of maturity (possible only in A. analis), the relationships between testes mass (TM) and TL and between $\mathrm{CL}$ and TL were examined for males, and between ovary mass (OM) and TL for females. Gonadosomatic index (GSI) was calculated as (gonad mass/body mass)*100, and where possible, compared between seasons. Average oviducal gland width (OGW) was calculated in mature females, and where

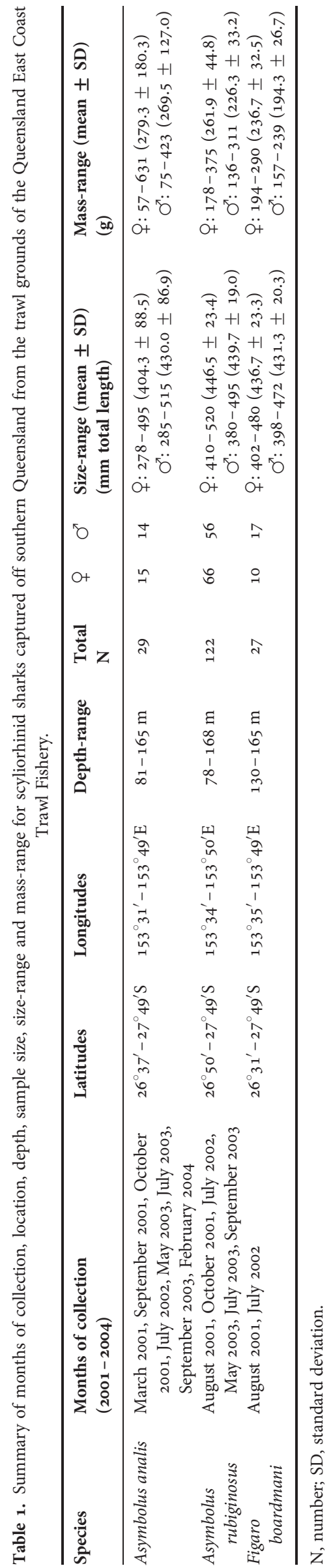


possible, compared between seasons. Follicle diameter was measured to the nearest millimetre and vitellogenic follicles (i.e. follicles $\geq 5 \mathrm{~mm}$ diameter) counted in the single functional ovary of mature females to determine ovarian fecundity. Maximum follicle diameter (MFD) of all individual mature females was compared between seasons. The relationship between the number of vitellogenic follicles and TL was examined using linear regression. The uteri of females were inspected for egg cases, which were counted if present. The proportion of mature females carrying egg cases was compared between seasons (possible only in A. rubiginosus).

Given low monthly sample sizes, samples were grouped by season (austral: summer, December-February; autumn, March-May; winter, June-August; spring, SeptemberNovember) to determine any seasonal trends in reproductive cycles. Significance was set at $P<0.05$. Statistical tests were performed using one-way analysis of variance (ANOVA), paired $t$-tests, and where data were non-normal and could not be normalized, the Mann-Whitney rank-sum test was used. The sex-ratio of the sample of each species was analysed using a Chi-square $\left(\chi^{2}\right)$-test.

\section{RESULTS}

One hundred and seventy-eight catsharks were collected (Table 1) (two A. analis and 11 F. boardmani were lodged in museum collections and thus were not available for internal dissection).

\section{Grey spotted catshark Asymbolus analis (Ogilby, 1885)}

Twenty-nine A. analis specimens were collected (Table 1). The length -frequency distribution of the specimens collected is shown in Figure 1A. The sex-ratio of 1.00:0.93 (female:male) did not differ significantly from $1: 1\left(\chi^{2}, \mathrm{df}=1, P=0.85\right)$.

The largest immature female was $310 \mathrm{~mm}$ TL and the smallest mature female was $455 \mathrm{~mm}$ TL. The relationship between TL and $\mathrm{OM}$ is shown in Figure $2 \mathrm{~A}$. Immature and adult individuals are easily separable on the graph; however, a lack of samples in between the largest immature female and the smallest mature female precludes an accurate assessment of the size at which $\mathrm{OM}$ increases rapidly with the onset of maturation (adolescent females were not observed) (Figure 2A). The majority of mature females sampled were collected during spring $(\mathrm{N}=7)$, with only a single mature female collected in each of autumn and winter, and none in summer. This limited the assessment of trends in female reproductive seasonality. Maximum follicle diameter observed was $24 \mathrm{~mm}$, and all mature females for which the ovaries could be examined contained follicles $\geq 17 \mathrm{~mm}$ diameter $(\mathrm{N}=9)$; as such, large-sized follicles were observed in all months and seasons sampled (Figure $2 \mathrm{~B}$ ). There was a significant relationship between the number of vitellogenic follicles (those $\geq 5 \mathrm{~mm}$ diameter) and TL (in $\mathrm{mm}$ ) in mature females (follicle number $=0.3084 \mathrm{TL}-132.2966, \mathrm{~N}=9, \mathrm{r}^{2}=0.66$, $P<0.008$ ) (Figure $2 \mathrm{C}$ ). The number of follicles per mature female ranged from 7-20. Of nine mature females examined, one ( $487 \mathrm{~mm} \mathrm{TL}$ ) captured in spring was carrying two egg cases, one in each uterus, with a second batch of egg cases coming through the oviducal glands. The MFD in this gravid female was $20 \mathrm{~mm}$.

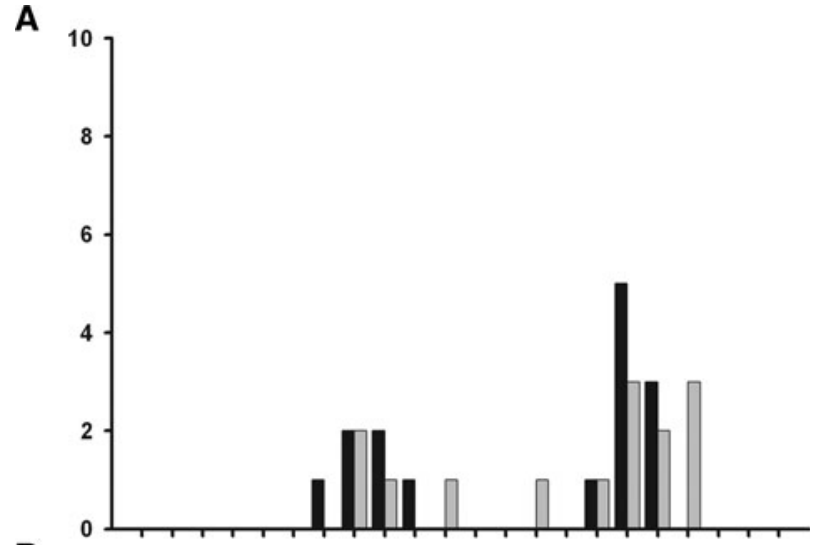

B

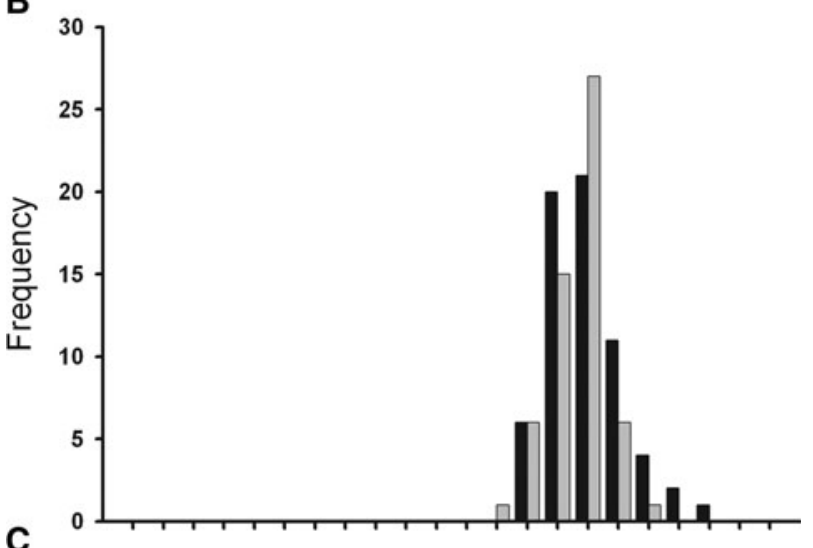

C

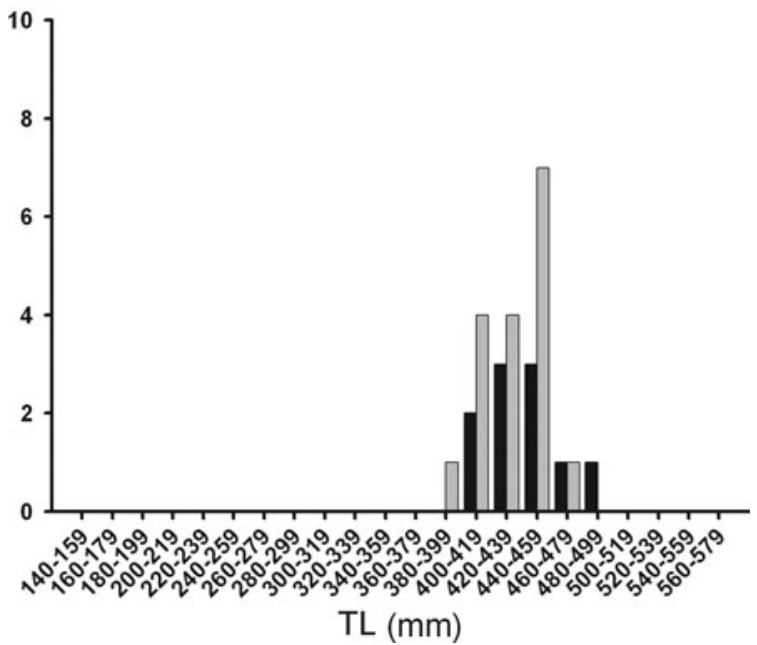

Fig. 1. Total length (TL) - frequency histogram for female (black bars) and male (grey bars): (A) Asymbolus analis; (B) Asymbolus rubiginosus; (C) Figaro boardmani. Note the different scales of the y-axis.

The largest immature male was $410 \mathrm{~mm}$ TL and the smallest mature male was $455 \mathrm{~mm}$ TL. The relationship between $\mathrm{TL}$ and $\mathrm{CL}$ is shown in Figure $2 \mathrm{D}$, and the relationship between TL and TM in Figure $2 \mathrm{E}$. Inner clasper length averaged $5.6 \%$ (range $4.7-6.5 \%$ ) of TL in immature males $(\mathrm{N}=$ 5) and $12.3 \%$ (range $11.4-13.1 \%$ ) of TL in mature males $(\mathrm{N}=9)$. Mature males were sampled, and GSI calculated, during all seasons, but low sample sizes (summer, $N=1$, $\mathrm{GSI}=2.92$; autumn, $\mathrm{N}=5, \mathrm{GSI}=2.75-4.06$; winter, $\mathrm{N}=$ 2 , GSI $=3.63-3.77$; spring, $\mathrm{N}=1$, GSI $=3.02$ ) limited the assessment of reproductive seasonality. 
A

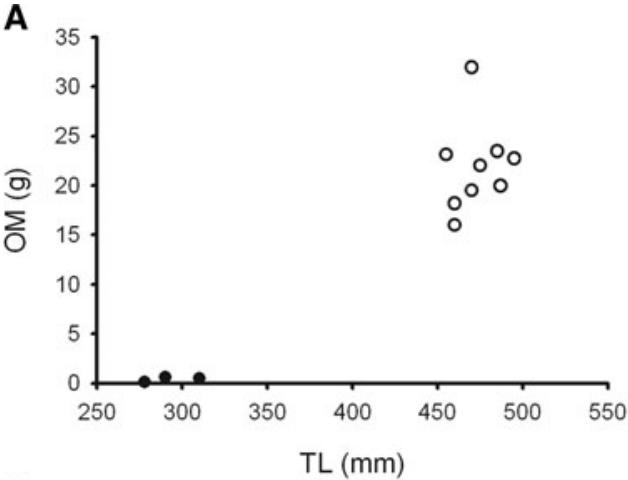

C

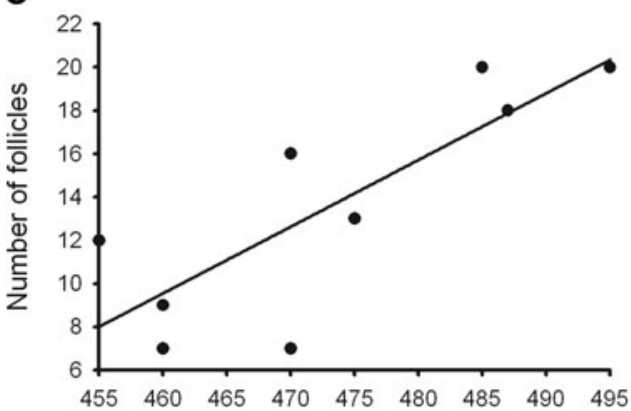

E

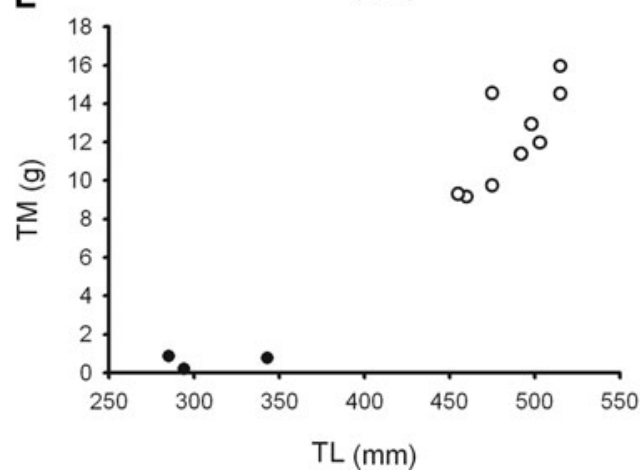

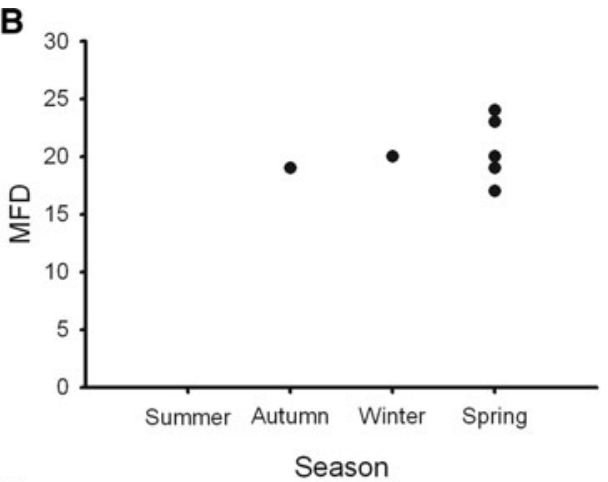

D

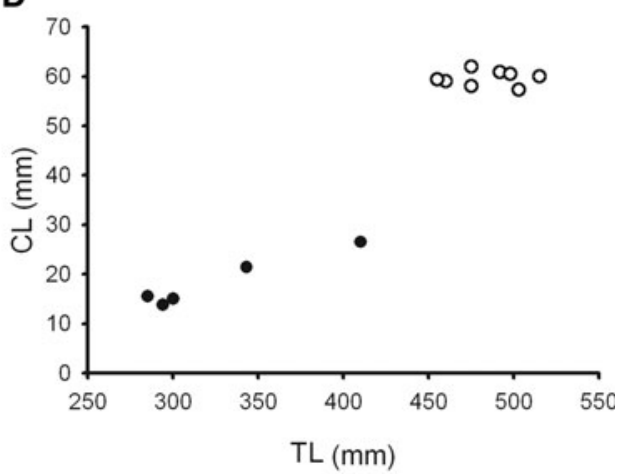

Fig. 2. Reproductive biology of female (A-C) and male (D-F) Asymbolus analis. (A) Relationship between total length (TL) and ovary mass (OM) for immature (closed circles) and mature (open circles) female A. analis; (B) maximum follicle diameter (MFD) versus season for female A. analis; (C) relationship between TL and the number of follicles for female A. analis; (D) relationship between TL and clasper length (CL) for immature (closed circles) and mature (open circles) male A. analis; (E) relationship between TL and testes mass (TM) for immature (closed circles) and mature (open circles) male A. analis.

\section{Orange spotted catshark Asymbolus rubiginosus Last, Gomon \& Gledhill, in Last, 1999}

One hundred and twenty-two A. rubiginosus specimens were collected (Table 1). The length-frequency distribution of the specimens collected is shown in Figure $1 \mathrm{~B}$. The sex-ratio of 1.00:0.86 (female:male) did not differ significantly from $1: 1$ $\left(\chi^{2}, \mathrm{df}=1, P=0.41\right)$.

No immature or adolescent female specimens were collected. The smallest mature female was $410 \mathrm{~mm}$ TL. Mature females were collected during autumn, winter and spring (although sample size was far greater in winter). Maximum follicle diameter observed was $17.2 \mathrm{~mm}$. Large-sized follicles were observed in all months and seasons sampled with overlap in MFDs between all seasons (autumn, 14.5-15.6 mm, $\mathrm{N}=8$; winter, $12.9-17.2 \mathrm{~mm}, \mathrm{~N}=47$; spring, 15.0-16.0 mm, N=2) (Figure 3A). There was a significant relationship between the number of vitellogenic follicles (those $\geq 5 \mathrm{~mm}$ diameter) and TL (in $\mathrm{mm}$ ) in mature females (follicle number $=0.0900 \mathrm{TL}-26.8819, \quad \mathrm{~N}=57$, $\mathrm{r}^{2}=0.37, P<0.0001$ ) (Figure $3 \mathrm{~B}$ ). The number of follicles per mature female ranged from 5-23. There was no significant difference in female GSI between seasons (ANOVA, $\mathrm{N}=63, \mathrm{~F}_{2,60}=1.026, P=0.37$ ) (Figure ${ }_{3} \mathrm{C}$ ). There was no significant difference in average oviducal gland width between seasons (ANOVA, $\mathrm{N}=65, \mathrm{~F}_{2,62}=0.994, P=0.38$ ) (Figure 3D). Of 65 mature females examined, 35 (410$520 \mathrm{~mm} \mathrm{TL}$ ) were carrying egg cases. The proportion of females carrying egg cases was highest in spring $(60 \%)$, intermediate in autumn (50\%) and lowest in winter (44\%) (Figure ${ }_{3} \mathrm{E}$ ). Of those females carrying egg cases, $14.3 \%$ had a single egg case in the left uterus, while the remainder carried a single egg case in each uterus. In those females carrying only a single egg case, the right uterus was expanded, suggesting that egg-laying had recently taken place. There was no significant difference in MFD between those females carrying egg cases and those that were not ( $t$-test, $\mathrm{N}=57$, 
A

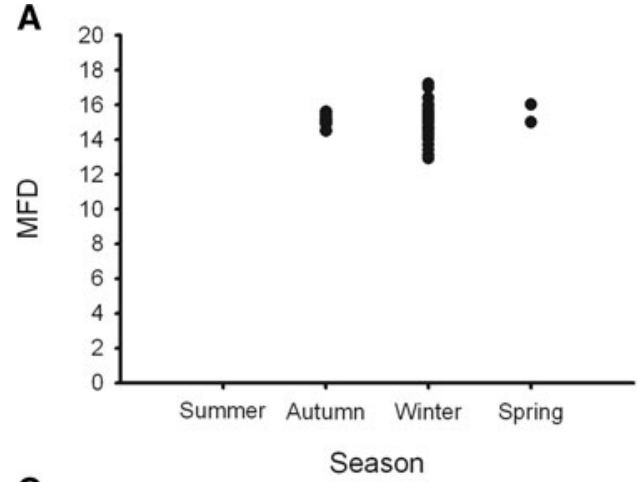

c

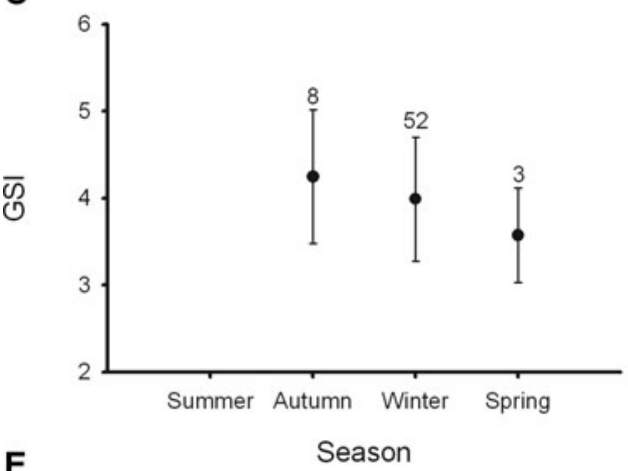

E

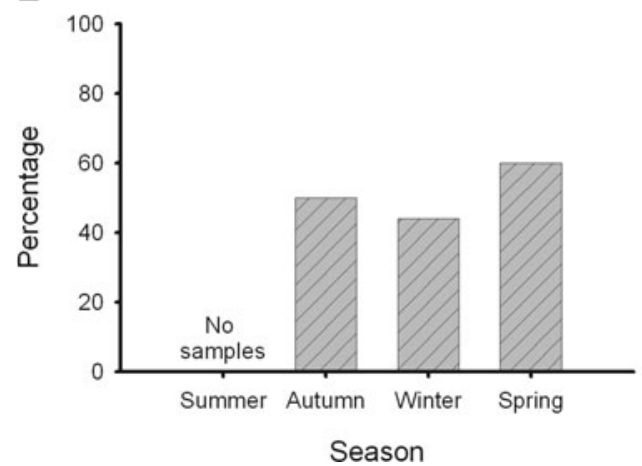

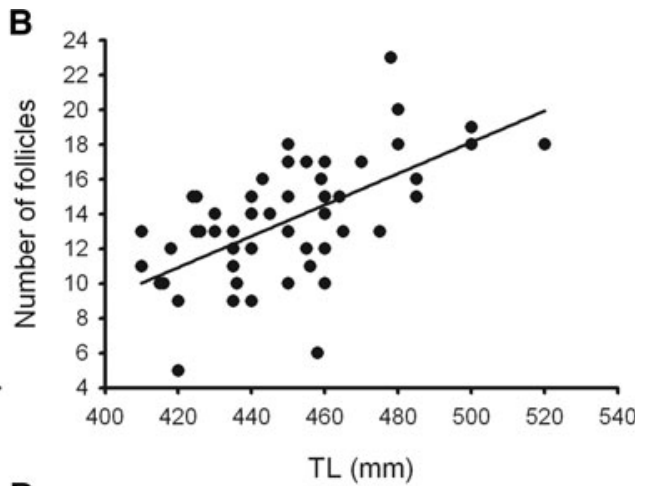

D

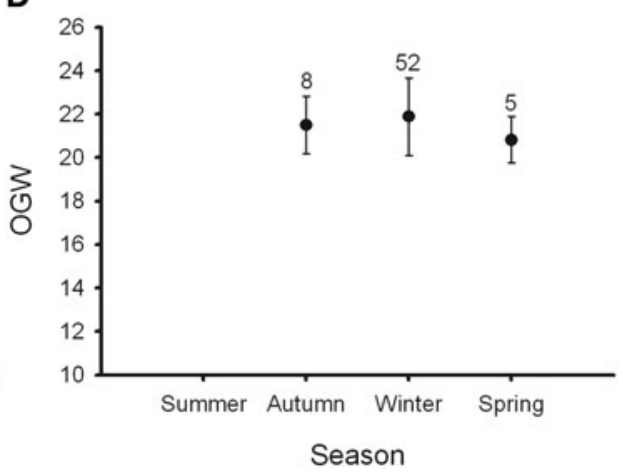

Fig. 3. Reproductive biology of female Asymbolus rubiginosus. (A) Maximum follicle diameter (MFD) versus season for female A. rubiginosus; (B) relationship between total length (TL) and the number of follicles for female A. rubiginosus; (C) gonadosomatic index (GSI) (mean \pm SD) versus season for female A. rubiginosus; (D) average oviducal gland width (OGW) (mean $\pm \mathrm{SD}$ ) versus season for female A. rubiginosus; (E) percentage of female A. rubiginosus carrying egg cases by season. Sample size shown above error bars.

$P=0.95)$. There was no significant difference in GSI between those females carrying egg cases and those that were not ( $t$-test, $\mathrm{N}=63, P=0.15$ ).

A male measuring $380 \mathrm{~mm}$ TL was immature and a male measuring $407 \mathrm{~mm}$ TL was adolescent. Two males were mature at $405 \mathrm{~mm} \mathrm{TL}$, as were all males $\geq 410 \mathrm{~mm} \mathrm{TL}$. Inner CL was $8.3 \%$ of TL in the immature male, $11.5 \%$ of TL in the adolescent male and averaged $12.1 \%$ (range $11.3-13.0 \%$ ) of TL in mature males $(\mathrm{N}=54)$. Mature males were collected during autumn and winter only. There was no significant difference in the GSI of mature males between these two seasons (Mann-Whitney rank-sum test, $\mathrm{N}=54, P=0.68$ ).

\section{Australian sawtail shark Figaro boardmani (Whitley, 1928)}

Twenty-seven $F$. boardmani specimens were collected (Table 1). The length-frequency distribution of specimens collected is shown in Figure $1 \mathrm{C}$. The sex-ratio of 0.59:1.00 (female:male) did not differ significantly from $1: 1\left(\chi^{2}, \mathrm{df}=1\right.$, $P=0.18)$.

No immature or adolescent female specimens were collected. The smallest mature female collected was $402 \mathrm{~mm}$ TL. All females sampled were collected during winter $(\mathrm{N}=10)$, which precluded any assessment of trends in female reproductive seasonality. Maximum follicle diameter observed was $19 \mathrm{~mm}$, and all mature females for which the ovaries could be examined contained follicles $\geq 16 \mathrm{~mm}$ diameter $(\mathrm{N}=5)$. The number of follicles per mature female ranged from 9-13. Of five mature females examined internally, four $(402-440 \mathrm{~mm}$ $\mathrm{TL}$ ) captured in winter were carrying egg cases; one with an egg case in each uterus and three with an egg case in only one uterus. The MFD in these gravid females was $16-19 \mathrm{~mm}$.

No immature male specimens were collected. The smallest mature male collected was $398 \mathrm{~mm}$ TL. Inner CL averaged $10.2 \%$ (range $9.3-11.3 \%$ ) of TL in mature males $(\mathrm{N}=17)$. All males sampled were collected during winter $(\mathrm{N}=17)$, which precluded any assessment of trends in male reproductive seasonality. 


\section{DISCUSSION}

Very few small-sized or immature catsharks were caught in the demersal trawl fishery from which specimens were collected for this study; no immature $F$. boardmani, no immature female $A$. rubiginosus, only two immature male A. rubiginosus and only a few immature $A$. analis were collected. The lack of small $A$. rubiginosus and $F$. boardmani collected does not appear to be explained by gear selectivity. Net body mesh sizes used were $\sim 50 \mathrm{~mm}$, and small-sized A. analis (from $278 \mathrm{~mm}$ TL) were captured. Additionally, many smaller teleost species were readily sampled (see Courtney et al., 2007). Many elasmobranchs segregate by size, occupying different bathymetric zones and this includes catsharks, for example Izak catshark Holohalaelurus regani (Gilchrist, 1922) (Richardson et al., 2000) and in parts of its range, blackmouth catshark Galeus melastomus Bonaparte, 1810 (see Capapé et al., 2008). Figaro boardmani is primarily a deeper water species $(130-640 \mathrm{~m})$ and it is possible that smaller individuals occupy deeper water than adults, which in the present study were collected from depths of $130-$ $165 \mathrm{~m}$. It is possible that smaller A. rubiginosus also occur primarily in deeper waters; both the immature and adolescent males were collected at depths close to the limit sampled (167 and $155 \mathrm{~m}$, respectively), while adults were collected at 78-168 m. However, the range of depths sampled here was too narrow to make any definitive statement on the relationship between size and depth in A. rubiginosus. There was no evidence of sexual segregation within the three species, with observed sex-ratios not differing significantly from 1:1.

Off southern Queensland, A. analis males appear to mature at between 410 and $455 \mathrm{~mm} \mathrm{TL}$, and females at under or about $455 \mathrm{~mm}$ TL. Previous estimates of male A. analis maturity have included $520 \mathrm{~mm}$ TL (Last \& Stevens, 1994) and $460 \mathrm{~mm}$ TL (Kyne et al., 2005; Last \& Stevens, 2009). The smallest mature female $A$. rubiginosus sampled was $410 \mathrm{~mm}$ TL, while Last \& Stevens (2009) list maturity at about $360 \mathrm{~mm}$ TL. Although Last et al. (1999) report that male $A$. rubiginosus mature at about $344 \mathrm{~mm}$ TL (no location given), a review of their paratype series shows that all males examined up to a size of $396 \mathrm{~mm}$ TL were immature (specimens from central to southern New South Wales). This is consistent with maturity in Queensland waters at sizes $>380 \mathrm{~mm} \mathrm{TL}$. Size at maturity for $F$. boardmani could not be determined because no immature individuals were sampled. Mature females and males have previously been reported at 430 and $400 \mathrm{~mm} \mathrm{TL}$, respectively (Last \& Stevens, 2009).

The catsharks are the sole elasmobranch family to display both oviparity and viviparity (see Kyne \& Simpfendorfer, 2010). The majority of species for which the reproductive mode has been confirmed are oviparous, although the reproductive mode of several species remains unknown (Ebert et al., 2006). Among the oviparous catsharks, both single oviparity and multiple oviparity have been documented. Single oviparity is defined by Francis (2006) (modified from Nakaya, 1975) as 'a single egg case is carried per uterus, and then deposited on the seabed at an early developmental stage', and multiple oviparity as 'multiple egg cases are retained in each uterus, and the embryos develop to an advanced stage before the eggs are deposited on the seabed'. Only single oviparity has been recorded in the genera Apristurus, Bythaelurus, Parmaturus and Scyliorhinus, and only multiple oviparity in Halaelurus, but both single and multiple oviparity occur in
Galeus (Cross, 1988; Compagno et al., 2005; Ebert et al., 2006; Francis, 2006). It appears that the genus Asymbolus displays single oviparity; both $A$. analis and $A$. rubiginosus were found to carry only one egg case in each uterus at a time. The Gulf catshark Asymbolus vincenti (Zietz, 1908), the only species of Asymbolus catshark for which there has been previously documented gravid females, also displayed single oviparity (Compagno et al., 2005). Figaro boardmani is also confirmed here as a single oviparous species.

Several indicators suggest that Asymbolus catsharks may be reproductively active year-round off southern Queensland. Large-sized follicles were observed in all months in which mature female A. analis (March, July, September and October) and mature female A. rubiginosus (May, July, August, September and October) were sampled. Furthermore, there were no differences apparent in gonadosomatic index or oviducal gland width between seasons for A. rubigniosus. These observations suggest that these species may have extended reproductive seasons, similar to that reported for other scyliorhinid sharks (e.g. Horie \& Tanaka, 2000; Richardson et al., 2000; Ebert et al., 2006; Capapé et al., 2008; Awruch et al., 2009). In $H$. regani off South Africa, there was no evidence of seasonality in the reproductive output of females (Richardson et al., 200o). Similarly, female G. melastomus have been observed to be reproductively active year round across the species' range (see Capapé et al., 2008). In contrast, some catsharks such as filetail catshark Parmaturus xaniurus (Gilbert, 1892) have defined reproductive seasons, with a peak in the proportion of gravid females from July to September (Flammang et al., 2008).

Reproductively active males have also been noted yearround in some catsharks, including in G. melastomus (Costa et al., 2005) and C. laticeps (Awruch et al., 2009). From the very limited data available for the two species of Asymbolus catsharks in the current study, there was no evidence that the male gonadosomatic index varied between seasons, although a more rigorous seasonal sampling protocol would be needed to resolve the reproductive periodicity of males of these species.

Even though significant patterns of reproductive seasonality may not occur in catsharks, there are often seasonal peaks in egg production (Cross, 1988; Horie \& Tanaka, 2000; Richardson et al., 2000; Costa et al., 2005; Ebert et al., 2006; Francis, 2006; Flammang et al., 2008; Awruch et al., 2009). Distinct seasonal peaks have been shown for G. melastomus off southern Portugal (Costa et al., 2005) and brown catshark Apristurus brunneus (Gilbert, 1892) in the eastern North Pacific (Cross, 1988; Flammang et al., 2008). Although egg-laying took place throughout the year by C. laticeps in southern Australian waters, Awruch et al. (2009) observed a peak laying period between January and June. While the proportion of A. rubiginosus females carrying egg cases off southern Queensland was similar across seasons sampled, it was highest in spring $(60 \%)$, intermediate in autumn $(50 \%)$ and lowest in winter (44\%) (there were no specimens collected during summer). It is therefore possible that, despite being reproductively active year-round, A. rubiginosus shows some seasonal variation in reproductive output.

Estimates of fecundity for oviparous catsharks are difficult to obtain if detailed data on the extent of the egg-laying season and egg-laying rates are absent. While egg-laying may be protracted across the year, peaks in production complicate estimates of annual fecundity. High fecundity was suggested for 
H. regani by Richardson et al. (2000) based on the large proportion of mature females carrying egg cases and a continuous reproductive cycle. In captivity, the chain dogfish Scyliorhinus retifer (Garman, 1881) was observed to lay pairs of egg cases at intervals of 14.1-16.7 days, resulting in an annual production of 44-52 egg cases (Castro et al., 1988). Several estimates of annual reproductive output are available for the small-spotted catshark Scyliorhinus canicula (Linnaeus, 1758): 29-62 egg cases per year (Ellis \& Shackley, 1997), 48-86 per year (Mellinger, 1983) and 45-190 per year (Capapé et al., 1991). Capapé et al. (2008) estimated a maximum of 97193 per year for G. melastomus. Unfortunately, such estimates are not available for the species studied here and counts of the number of vitellogenic ovarian follicles can only serve as a proxy for calculating reproductive output. These counts ranged from 7 to 20 in A. analis, 5 to 23 in A. rubiginosus and 9 to 13 in $F$. boardmani. Significant relationships were observed between maternal size and the number of vitellogenic follicles in A. analis and A. rubiginosus, suggesting higher potential reproductive output in larger females. The relationship between fecundity and ovarian follicle number needs to be explored more widely in oviparous species to assist in the interpretation of limited data sets from difficult to sample or naturally rare species.

Despite their diversity, there are few biological data available on Australian scyliorhinid sharks; indeed these species are some of the most poorly known of the Australian shark fauna. The results of the present study should be treated as preliminary and interpreted with caution, as grouping samples by season may mask smaller-scale (e.g. monthly) temporal trends, as well as inter-annual variation. These trends are difficult to assess in species such as A. analis, A. rubiginosus and F. boardmani off southern Queensland where sampling is restricted by the limited operating season of the commercial fishery in which the species are encountered.

\section{ACKNOWLEDGEMENTS}

The authors thank the commercial fishers who assisted with fish collection, in particular Peter Gaddes, Phil Pearson and Mark Welbeloved. Thanks are also extended to Matthew Campbell, Keith Chilcott and Mark Tonks of the Southern Fisheries Centre for assistance in the field and in processing specimens, to Tracey Scott-Holland for assistance in the laboratory, and to Micha Jackson for comments on the manuscript. Specimens were collected under Queensland Fisheries Service General Fisheries Permits PRMo236oD, PRMo2030C and PRMo3951I. Collection of material was funded by the Fisheries Research and Development Corporation as part of a broader research project (FRDC 2000/170). P.K. was funded by an Australian Postgraduate Award.

\section{REFERENCES}

Awruch C.A., Pankhurst N.W., Frusher S.D. and Stevens J.D. (2008) Endocrine and morphological correlates of reproduction in the draughtboard shark Cephaloscyllium laticeps (Elasmobranchii: Scyliorhinidae). Journal of Experimental Zoology 309A, 184-197.

Awruch C.A., Pankhurst N.W., Frusher S.D. and Stevens J.D. (2009) Reproductive seasonality and embryo development in the draughtboard shark Cephaloscyllium laticeps. Marine and Freshwater Research 60, 1265-1272.

Capapé C., Tomasini J.A. and Bouchereau J.L. (1991) Observations sur la biologie de la reproduction de la petite roussett Scyliorhinus canicula (Linnaeus, 1758) (Pisces, Scyliorhinidae) de Golfe du Lion (France Méridionale). Ichtyophysiologica Acta 14, 87-109.

Capapé C., Guélorget O., Vergne Y. and Reynaud C. (2008) Reproductive biology of the blackmouth catshark, Galeus melastomus (Chondrichthyes: Scyliorhinidae) off the Languedocian coast (southern France, northern Mediterranean). Journal of the Marine Biological Association of the United Kingdom 88, 415-421.

Castro J.I., Bubucis P.M. and Overstrom N.A. (1988) The reproductive biology of the chain dogfish, Scyliorhinus retifer. Copeia 1988, 740746.

Compagno L.J.V. (2005) Global checklist of living chondrichthyan fishes. In Fowler S.L., Cavanagh R.D., Camhi M., Burgess G.H., Cailliet G.M., Fordham S.V., Simpfendorfer C.A. and Musick J.A. (eds) Sharks, rays and chimaeras: the status of the chondrichthyan fishes. Status survey. Gland, Switzerland and Cambridge, UK: IUCN, pp. 401-423.

Compagno L., Dando M. and Fowler S. (2005) A field guide to sharks of the world. London: Harper Collins.

Costa M.E., Erzini K. and Borges T.C. (2005) Reproductive biology of the blackmouth catshark, Galeus melastomus (Chondrichthyes: Scyliorhinidae) off the south coast of Portugal. Journal of the Marine Biological Association of the United Kingdom 85, 1173-1183.

Courtney A.J., Haddy J.A., Campbell M.J., Roy D.P., Tonks M.L., Gaddes S.W., Chilcott K.E., O’Neill M.F., Brown I.W., McLennan M., Jebreen E.J., van der Geest C., Rose C., Kistle S., Turnbull C.T., Kyne P.M., Bennett M.B. and Taylor J. (2007) Bycatch weight, composition and preliminary estimates of the impact of bycatch reduction devices in Queensland's trawl fishery. Final Report FRDC Project No. 2000/170, 307 pp.

Cross J.N. (1988) Aspects of the biology of two scyliorhinid sharks, Apristurus brunneus and Parmaturus xaniurus, from the upper continental slope off southern California. Fishery Bulletin 86, 691-702.

Ebert D.A., Compagno L.J.V. and Cowley P.D. (2006) Reproductive biology of catsharks (Chondrichthyes: Scyliorhinidae) off the west coast of southern Africa. ICES Journal of Marine Science 63, 10531065 .

Ellis J.R. and Shackley S.E. (1997) The reproductive biology of Scyliorhinus canicula in the Bristol Channel, U.K. Journal of Fish Biology 51, 361-372.

Flammang B.E., Ebert D.A. and Cailliet G.M. (2008) Reproductive biology of deep-sea catsharks (Chondrichthyes: Scyliorhinidae) in the eastern North Pacific. Environmental Biology of Fishes 81, 35-49.

Francis M.P. (2006) Distribution and biology of the New Zealand endemic catshark, Halaelurus dawsoni. Environmental Biology of Fishes 75, 295-306.

Horie T. and Tanaka S. (200o) Reproduction and food habits of two species of sawtail catsharks, Galeus eastmani and G. nipponensis, in Suruga Bay, Japan. Fisheries Science 66, 812-825.

Kyne P.M. and Simpfendorfer C.A. (2010) Deepwater chondrichthyans. In Carrier J.C., Musick J.A. and Heithaus M.R. (eds) Sharks and their relatives II: Biodiversity, adaptive physiology, and conservation. Boca Raton, FL: CRC Press, pp. 37-114.

Kyne P.M., Johnson J.W., Courtney A.J. and Bennett M.B. (2005) New biogeographical information on Queensland chondrichthyans. Memoirs of the Queensland Museum 50, 321-327.

Last P.R. and Stevens J.D. (1994) Sharks and rays of Australia. Hobart: CSIRO Division of Fisheries. 
Last P.R. and Stevens J.D. (2009) Sharks and rays of Australia. 2nd edition. Collingwood: CSIRO Publishing.

Last P.R., Gomon M.F. and Gledhill D.C. (1999) Australian spotted cat sharks of the genus Asymbolus (Carcharhiniformes: Scyliorhinidae) Part 2: descriptions of three new, dark-spotted species. In Last P.R. (ed.) Australian catsharks of the genus Asymbolus (Carcharhiniformes: Scyliorhinidae). Hobart: CSIRO Division of Marine Research, pp. 19-35. [CSIRO Marine Laboratories Report, No. 239.]

Mellinger J. (1983) Egg-case diversity among dogfish, Scyliorhinus canicula (L.): a study of egg laying rate and nidamental gland secretory activity. Journal of Fish Biology 22, 83-90.

Nakaya K. (1975) Taxonomy, comparative anatomy and phylogeny of Japanese catsharks, Scyliorhinidae. Memoirs of the Faculty of Fisheries, Hokkaido University 23, 1-94. and

Richardson A.J., Maharaj G., Compagno L.J.V., Leslie R.W., Ebert D.A and Gibbons M.J. (2000) Abundance, distribution, morphometrics, reproduction and diet of the Izak catshark. Journal of Fish Biology $56,552-576$

\section{Correspondence should be addressed to:} Peter M. Kyne

Tropical Rivers and Coastal Knowledge Charles Darwin University

Darwin, Northern Territory, 0909, Australia email: peter.kyne@cdu.edu.au 